Journal of History Culture and Art Research (ISSN: 2147-0626)

Tarih Kültür ve Sanat Araştırmaları Dergisi

Vol. 9, No. 1, March 2020

\title{
DOI: 10.7596/taksad.v9i1.2402
}

Citation: Moskalyova, L., Maksymov, O., Gurov, S., Gurova, T., \& Yakovleva, V. (2020). Pedagogy of Argumentation: Teaching the Skills of Argumentation to Older Teens. Journal of History Culture and Art Research, 9(1), 156-171. doi:http://dx.doi.org/10.7596/taksad.v9i1.2402

\section{Pedagogy of Argumentation: Teaching the Skills of Argumentation to Older Teens}

\author{
Luydmyla Moskalyova ${ }^{1}$ Oleksandr Maksymov² \\ Serhiy Gurov ${ }^{3}$ Tetyana Gurova ${ }^{4}$ Viktoria Yakovleva ${ }^{5}$
}

\begin{abstract}
The article deals with the problem of training future teachers to teach older teens the ability of argumentation as an intellectual and communicative activity. The authors analyze the specifics of the training of future teachers in higher education institutions; the process of formation of the competence of teaching the ability of argumentation; the development of pedagogy of argumentation in higher education institutions. The current stage of the education system development requires improving the level of teachers' training. The problem of professional competence of future teachers who acquire the method of teaching students the ability of argument is relevant. At the same time, there is a need to develop a special professional quality of the future teacher - to be able to defend their own point of view, to formulate theses, to effectively build a system of arguments during communication. So, the issue has a complex character - university students should be taught pedagogical argumentation, they should be equipped with the corresponding technique in order their future pupils gain an opportunity to realize successfully the structure of argumentation both in written and spoken communication. The purpose of the article is to determine the features of teaching methods used at secondary school when forming pupils' ability of argumentation. This paper aims to identify the main approaches to teaching argumentation, to find out the level of future teachers' readiness to teach students the ability of argumentation, to develop an experimental method of teaching pedagogy of argumentation and check its results. We conducted an experimental study with 44 students of the Bogdan Khmelnitsky Melitopol state pedagogical university and State Higher Educational Institution Krivoy Rog State Pedagogical University in Ukraine for two years (2018-2019). We divided students into control and experimental groups and provide an extensive education to the control group. The results suggest that the control group's argumentation skills increased significantly. In drawing conclusions, we note that the proficiency of the teaching methods of older adolescents affects the professional and a future teacher's personal qualities.
\end{abstract}

Keywords: Argumentation, Humanitarian education, Pedagogical argumentation, Methods of teaching argumentation.

\footnotetext{
${ }^{1}$ Bogdan Khmelnitsky Melitopol State Pedagogical University, Ukraine. E-mail: moskalevalu1@gmail.com

2 Bogdan Khmelnitsky Melitopol State Pedagogical University, Ukraine. E-mail: maksimov_oleksandr@mdpu.org.ua

${ }^{3}$ Bogdan Khmelnitsky Melitopol State Pedagogical University, Ukraine. E-mail: serggurov@ukr.net

${ }^{4}$ Bogdan Khmelnitsky Melitopol State Pedagogical University, Ukraine. E-mail: tatianagurova2017@gmail.com

${ }^{5}$ Technological Education of State Higher Educational Institution «Krivoy Rog State Pedagogical University, Ukraine. E-mail: iakovleva.dpn@gmail.com
} 


\section{Introduction}

According to the recommendation of the European Parliament and the Council of the European Union "On basic competencies for lifelong learning" (206/962/EC) and the Law of Ukraine "On education", the educational institutions should help to acquire key competencies that would allow to carry out professional activities in the chosen field. One of the significant problems faced by many modern students is the inability to argue their point of view.

Future teachers demonstrate monotonous ways of persuasion and insufficient mastery of speech influence on the school audience when they have an apprenticeship at school. Students seldom show the ability to influence the audience by facial expressions, gestures, visual images, etc., that means they did not master the art of argumentation during training.

At universities, training future teachers to overcome pedagogical argumentation is carried out in different ways. In most universities, teachers pay attention to the students' mastery of different teaching methods of such subjects as Ukrainian and foreign languages, math, chemistry, etc. Future teachers are introduced to the theoretical foundations of argumentation in various courses - "Philosophy", "Logic", "Rhetoric", "Psychology", "Ukrainian language for professional orientation" and others. However, at these courses, there is no attention paid to the development of students' readiness to teach pupils the ability of argumentation.

The availability of educational materials that would reveal the essence of various methods of teaching argumentation, which the student could master on their own, is also insufficient. We are interested in the level of readiness of future teachers to teach pupils the ability and skills of argumentation. We search for the content of main classes for students in the classroom, and some extracurricular activities (outside the university) that help to improve the quality of teaching pedagogy of argumentation.

\section{The concept of teaching pedagogy of argumentation}

There is a recent interest in the discussion on the issue of argumentative skills development (Erdogan, Ciftci, \& Topcu, 2017; Archila, Luna-Calderon, \& Mesa-Pineros, 2017). The need to study the argumentative skills both in higher and secondary schools (Mitchell \& Andrews, 2000; Costello \& Mitchell, 1995) and in early childhood (Costello, 2000) is addressed as well. There have been discussions on the choice of subjects where secondary school teachers should teach their students the skills of argumentation (Torun \& Şahin, 2016; Namdar \& Tuskan, 2018). Also, there are opinions about the need to teach the theory and methodology of the formation of argumentation skills while training secondary education teachers (Volkova, 2010; Bërveniku, 2017).

The concept of teaching pedagogy of argumentation contradicts the previous materials of the authors in some sense. The need to develop critical thinking, which is sometimes substituted for teaching argumentation pedagogy, should not turn the future teacher into a follower of eristics, who teaches the use of unfair means in a dispute, which can significantly exacerbate the confrontation between different opinions. It is also believed that in difficult periods of growing up of the individual (and this is the age period - older adolescence) training arguments, which has a confrontational nature, comes into conflict with the training of socio-cultural norms of society (Bathgate, Crowell, Schunn, Cannady, \& Dorph, 2015).

The activity of future teachers is motivated by identifying ethical norms of argumentation (moral judgments) and moral and ethical values when being taught pedagogy of argumentation. Let us name main of them - pedagogical love and pedagogical justice, the beauty of the pedagogical action. Thought processes, in this case, are in harmony with the processes of personal and professional development of students, as our values and reliance on them in teaching encourage 
conscious behavior and critical perception of argumentation methods. The direction of argumentation pedagogy is based on the main provisions of the metamethodic approach (Valitskaya, Antonova, \& Zhigalko, 2006), the modern theory of argumentation "new rhetoric" (Ivin, 2015), the theory of modern rhetoric (Andrews, 2013), the theory of mentality (Gershunsky, 1998), the theory of moral reflection (Lefevr, 2009), humanitarian principles (reflexivity, interactivity, projectivity) of teacher's professional education (Borytko, 2012). In this case, the pedagogy of argumentation is filled with new content, new forms and methods of teaching in higher education.

\section{Main approaches to argumentation training}

There are several approaches to teaching argumentation. Among them are the following: 1) activity approach to learning, 2) a systematic approach to teaching reasoned skills and abilities; 3 ) a dialogical approach to teaching argumentation pedagogy.

The activity approach to teaching argumentation is based on the works of L. Vygotsky (1991), O. Tikhomirov (1984), D. Llewellyn (2013), etc. The activity of teachers and students in the development of reasoning skills through an active approach has a special structure, which has motives, purpose, means, result, cycle, and process of implementation. During the training of argumentation skills, there is formed a way of thinking, the style of behavior in the society is provided. This approach to learning the skills of argumentation allows the use of such activities: a game, knowledge, speech, and creativity.

According to $\mathrm{H}$. Hekhauzen (2003), there are some functional components of the activities, among them we should mention perception, thinking, and learning, reproduction of knowledge, speech and motor activity. As D. Llewellyn (2013) emphasizes, the majority of teachers think about what is more important: the study of the laws and concepts that overwhelm the curriculum, or scientific argument teaching?

Let us also note the main provisions highlighted in the work of O. Tikhomirov (1984):

- polymorphism of human thinking (the need to take into account the diversity of types of thinking during the training of argumentation skills);

- common structure of theoretical (mental) activity and practical (subject) activity (the need to study the motivation of theoretical activity of students) (Tikhomirov, 1984).

The postulate by O. Tikhomirov - "thinking as action" allowed him to put forward the best method for studying the processes of thinking - self-observation. Do future teachers need to be trained in self-observation processes? We believe that the teacher should contribute to the organization of students' self-observation processes. These processes can be the basis for: 1) development of recommendations for professional development in the field of pedagogy of argumentation; 2) formation of individual abilities necessary for teaching pedagogy of argumentation; 3 ) identification of personal judgments about the attitude of future teachers to the peculiarities of the process of teaching argumentation of older adolescents, which affects their readiness in this type of activity.

A systematic approach to learning, including the ability and skills of argumentation, is based on the works of such scientists as: W. F. Roth and I. M. Roth (2015), R. N. Shambaugh and S. Magliaro (2006), R. Killen (2006), H. Fry, S. Ketteridge, and S. Marshall (2003), R. Andrews (1995; 2009), etc.

A systematic approach is very important in higher education as H. Fry et al. (2003) indicate, it is explained by its close relation to the learning outcomes. Essential principles of this approach lay in the relationship between different stages of training, consistency and integration of course materials. Course planning should be focused students' needs and capabilities. The authors point out: "because 
the model of systematic planning is both useful for the process of organizing teaching and learning and contributes to the implementation of the results-based approach to the development of the course/module..." (Fry et al., 2003).

The idea of developing the potential of each student is contained in the works of W. F. Roth and I. M. Roth (2015). They allege that educators should shift their focus from "ethics of growth" to "ethics of development": "an increasing number of educators are also beginning to realize that if we want to continue to progress as a nation, we need to move to an ethics of development where more attention should be paid to developing the unique potential of each student" (Roth \& Roth, 2015).

R. N. Shambaugh and S. Magliaro (2006) also believe that teachers should use a systematic approach in the development of training instructions. Educational design the authors call a systematic tool that helps to make clear pedagogical decisions based on the results of training, assessment, and technology.

According to R. Killen (2006), a systematic approach to learning takes into account such important principles as integration and interconnections in the planning of the whole learning process: 1) long-term (several years); 2) medium-term (a period of several weeks, a separate topic as a unit of work), 3) short-term (lesson after lesson). The author points out: "you cannot expect individual lessons to succeed unless they have been carefully planned and integrated into your medium-and long-term plans. There should be a direct and obvious connection between what you do lesson after lesson and what the program offers students to learn in the long run" (Killen, 2006).

R. Andrews (1995) argues that teaching and learning argumentation is a central component of the curriculum. According to the scientist, the function of the argument is very broad and that is the argument, which is necessary for the development of thinking skills at different age stages (from education in early childhood to university education). According to the scientist, the argumentation is divided into oral, written and visual. It is important for the higher education system to distinguish between the argument "as a product" and the argument "as a result".

In discussing the basic rules of argumentation, R. Andrews (1995) points to the students' propensity to rely on the argumentation skills they acquired in the previous stage of their formal education: "In the case of submitting assignments in higher education - especially if there is little in the way of advice or guidance on the content, structure, and format of what is expected - students are likely to fall back upon genres and practices that they know from the previous stage of education and in which, in all probability, they were successful". (Andrews, 2009).

The dialogical approach to argumentation training is based on the work of such scientists as V. Bibler (1993), A. B. Lourenço, J. Q. Ferreira, and S. L. Queiroz (2016), C. Villarroel, M. Garcia-Mila, M. Felton, and A. Miralda Banda (2019), etc.

The dialogic approach involves the organization of the process of teaching pedagogy of argumentation so that students do not just learn the knowledge and skills, but can determine the essence of branched concepts, recognize and use dialogic strategies, apply the objectives of argumentation in various cases. In this sense, higher pedagogical education assumes the presence of "points of surprise" (Bibler, 1993).

The scientist refers to such points: "the idea of the word; the idea of number; the idea of natural phenomena; the concept of a moment in history; riddles of consciousness; mysteries of the subject guns" (Bibler, 1993). We believe that the use of "points of surprise" will interest future teachers to learn new ideas and meanings, features of the terminological field of pedagogy of argument. 
The study on the inclusion of argumentative practice by C. Villarroel et al. (2019) convincingly shows the importance of a dialogical approach in future teachers' training. According to the authors, it is the dialogue that has a positive impact on the quality of argumentation training. Argumentative goals, in their opinion, are the determining factors in argumentative discourse. To these goals, the authors refer compelling and meaningful goals, and also the objectives of the deliberation, which, in contrast to the convincing goals, provide a lower capacity for scientific knowledge.

A. B. Lourenço et al. (2016) also write about the need for teachers to apply dialogue approaches. In their opinion, it involves students in the discussion and develops argumentation skills. The authors point out that one of the goals of scientific education is the development of students' critical thinking. As a basis for a dialogue, one should use reflections on scientific discoveries, social and scientific issues. This work involves the development of various models, including discussion, explanation, interpretation of phenomena. According to the authors, the teacher plays a fundamental role in teaching argumentation. One of the factors that should be taken into account in the training of argumentation is the formulation of questions about the goals of didactic activity of students. Accordingly, it is the effective participation of students that is ensured when the teacher "asks for a description of the solution and an explanation of the answers". For this purpose, both oral and written argumentation should be used, according to the authors.

\section{Theoretical and methodical points in teaching pedagogy of argumentation}

What is the theoretical basis for the study of argumentation? As R. Andrews (2013) writes, this is rhetoric: "Everyday life in a democracy is a matter of negotiations. While some practices will be habitual and thus seem "thoughtless," these habits will be the result of a decision-making process based on the thought and argument" (Andrews, 2013). However, the author does not consider rhetoric synonymous to argumentation. Argumentation, in his opinion, is only one of the areas of rhetoric. Both rhetoric and argumentation are important for learning in a modern democratic society. The central characteristic of the argument, as Richard Andrews writes, is the refutation of hypotheses: "The refutation of hypotheses is the most obviously central characteristic of argument, linked closely to the freedom to oppose, to reject, and, indeed, to rebut refutations" (Andrews, 2013).

Agreeing with the opinion of the author, we emphasize that for the training of argumentation skills at school, the future teacher needs to form his own accumulated stock of opportunities (knowledge and skills). To create a method of teaching argumentation, it is necessary to take into account that motivation plays an important role in learning. It is a motivation that encourages future teachers to study hard and to achieve results intensively. Thus, the activity approach to teaching argumentation skills allows future teachers:

1) to perceive ideas, facts, theories, terms, laws of pedagogy of argumentation;

2) to process the acquired knowledge, to learn the essence of the needs of students in the teaching of argumentation, to increase the amount of knowledge about the learning process of argumentation;

3) analyze argumentation teaching methods that are more accessible for different age students;

4) to provide an interpretation of the received information on the results of argumentation skills training in various processes of dialogue communication, cinema and theater scenes, works of art and literary texts for older teenagers in order to explain their value sense;

5) apply the necessary methods of diagnosing the process of learning the skills of argumentation; 
6) to evaluate the material and exercises aimed at teaching older teens the argument;

7) develop new plans and programs of argumentation training on the basis of the acquired knowledge.

The functional components of the activity of the future teacher in the field of pedagogy of argumentation also concern the teaching of the skills of mimicry, gestures, tone of voice, etc., as well as the ability to interpret them.

In the process of teaching pedagogy of argument, a future teacher must learn to see a student's purpose and help in achieving it. We believe that during their studies at the university future teachers should be aware of the components of argumentation training, effective forms and methods of training. Future teachers should also have the tools of diagnosing students' skills based on their age capabilities to formulate statements with evidence, build arguments, voice their position, work out alternative opinions and be able to respond to them. Moreover, future teachers should understand what teaching methods are necessary for drawing conclusions, what exercises are necessary for the development of the ability to listen and the ability to speak.

The forefront of pedagogical reasoning takes the training of future teachers of methodical ways of using essays, an experiment, some cognitive tasks of creative or methodological type for the formation of concepts of the studied scientific basics. Students can be convinced of the correctness of their own actions leading to the goal only through the result of an essay, experiment or any solved cognitive problem.

We give one example. At the lesson of studying the native language and literature, the teacher offers students to prepare an essay-reflection. The main algorithm of the task: 1) the formulation of the main thesis with the accompanying information; 2) the formulation of an additional thesis with additional information; 3 ) the formulation of the conclusion with the evidence of the author's advantages. This essay-reflection is proposed to write, using 10 words (thematic construct) selected on the topic of the lesson. In the text of the essay-reflection, these words are proposed to be highlighted in a different color (to visualize the thematic construct).

After the preparation of essays, the students exchange their notebooks. The purpose of the exchange of notebooks - familiarization with the composition and making proposals to supplement the text of alternative positions to improve the composition.

The teacher ensures that the atmosphere of openness, friendliness, mutual assistance reigned in the lesson. After finishing the job, the best essay is awarded with applause.

What is important in teaching argumentation? Scientists come to the conclusion that it is important to create an appropriate atmosphere. Let us emphasize D. Llewellyn's (2013) opinion on the key factors that testify the presence of such an atmosphere: "openness to ask questions and seek answers, commitment to critical thinking and metacognitive skills, ownership and self-study, teamwork, willingness to learn new ideas, holiday for student success, and respect for another's point of view" (Llewellyn, 2013).

It is important to learn how to analyze the processes of strengthening or weakening of the students' argumentation skills. It is necessary to learn the methods of pedagogical research, including observation, conversation, survey, questioning, testing for such an analysis. It is relevant to take into account the provision that students of such a difficult age period are brought up in different environments and fall into different (both favorable and unfavorable) situations. The future teacher, taking into account such situations, should learn to consider the process of learning argumentation from different levels. To such levels, we refer: 1 ) how has the motivation of the student in teaching argumentation skills changed in the situation? 2) What were the student's stimuli 
to improve (degrade) the process of learning argumentation skills? 3) Who did the student meet immediately before the situation that led to changes in the process of learning argumentation skills? 4) Is this situation typical for a given age or did the student react unusually? 5) What environment is the student in (favorable or unfavorable) for his training?

The future teacher should understand the importance of the student's environment, which influences his / her learning activity. In this regard, we emphasize the idea of S. Rubinstein that every human action "comes from certain motives and is directed to a specific purpose; it solves a particular problem and expresses a certain attitude of man to the environment" (Fundamentals, 2003).

Analysis of the works of scientists (Llewellyn, 2013; Bathgate et al., 2015; Acar, Patton, \& White, 2015) allowed formulating such postulates:

1. The development of the future teacher's readiness to teach the skills of argumentation of older adolescents occurs through a number of interrelated stages: 1) creating an atmosphere for rational mental activity in the field of knowledge of their abilities to an argument - in written, oral and visual form; 2) arousing interest in the values of the teaching profession; 3 ) the study of ethical norms of argumentation; 4) creating a personal portfolio of basic and additional abilities that will make a professional readiness to teach the skills of argumentation of older adolescents; 5) testing of materials for teaching argumentation skills in practice and evaluation of results; 6) reflection of the process of development of readiness for argumentation training.

2. Education of students of pedagogy of argumentation as for the changes in thought processes and verbal behavior. The future teacher, as a subject of meta-activity, should understand their individual psychological characteristics (gnostic, expressive, intersocial, creative, linguistic, organizational, didactic, perceptive, suggestive, scientific and cognitive abilities) and be able to relate them to those individual psychological characteristics possessed by older adolescents. In this regard, it is important to develop special training that will affect the following meta-skills:

- general diagnostics of the logical-communicative process in the classroom;

- setting a goal in teaching argumentation for each student, taking into account the existing potential and individual psychological characteristics;

- forecasting the results of the development of students' argumentation skills;

- selection of exercises, experiments, tasks, and development of new tools for teaching argumentation skills in accordance with the individual psychological characteristics of the student.

3. Both formed professional readiness of the student to learn the skills of argumentation, and unpreparedness can be used to create situations of development that will further improve the content of pedagogy of argumentation, the development of guidelines.

The results of teaching future teachers the pedagogy of argumentation should be the first step towards teaching in higher education. And the principles, stages, sequence, orientation to the needs of the student are essential in the teaching pedagogy of argumentation. In this case, the formation of the readiness of students to learn the skills of argumentation should be based on the following provisions:

1. Teaching the pedagogy of argumentation should enrich the content of the higher education system with new theoretical provisions and methods of teaching, the introduction of a new academic discipline, conducting extracurricular work outside the University (for example, leisure activities, among which may be: the organization of theatrical productions, work in student television, participation in competitions, laughter leagues, debates, discussions, etc.). 
2. The process of improving the readiness of argumentation training has specific features. It should not be categorical, because at all stages of the development of specific abilities of students may meet restrictions. These limitations should be perceived as a set of methodological difficulties to be solved through the search for new ideas.

3. The process of improving the readiness to learn the skills of argumentation should be considered in a holistic system, which involves the use of principles such as consistency, manageability, forecasting. These principles allow us to reduce such a feature in learning how the randomness.

In teaching pedagogy of argumentation, it is necessary to use communicative and dialogical strategies, which are joined by students and teachers of the University. We propose to teach future teachers several types of strategies (presentation, manipulation, opposition, convention). It should be noted that each of these strategies has its own means of expression. So, if a manipulative strategy is used by unreasoned posts, whereas presentation of the strategy - reasoned message. For the opposition strategy, the dialogue uses polemics as a special competition aimed at persuading the other side, while the conventional strategy contains the basis for dialogue - understanding, empathy, focus on the value of human life and health. Thus, to teach the pedagogy of argumentation, we can deduce several provisions:

1. The future teacher plays an important role in teaching the arguments of older teenagers. Since the older age period is one of the most difficult, it is necessary to apply such examples of argumentation training, which will be aimed at the safety and harmony of human life, and not the doctrine of arguing and persuading for the sake of personal self-assertion and their own benefits and immediate success.

2. Discussion, explanation and interpretation of phenomena in the teaching of argumentation skills should be focused on the development of humanity in the student, and for this it is necessary to focus on the positive qualities of the student.

3. Future teachers should be informed about all available communication strategies, but it is strictly forbidden to use manipulative and oppositional strategies in teaching older adolescents, as they are in conflict with the teaching of social and cultural norms of society at this difficult age.

\section{Levels of readiness of future teachers to teach students the ability of argumentation}

We can state the fact that in modern conditions of practice of teaching future teachers at the university, not many students have a high level of readiness to teach older adolescents the skills of argumentation. At the same time, many have theoretical knowledge about the purposes of argumentation, about the ways of laying the foundations for any idea. However, most future teachers do not know how to teach argumentation, and do not know in what conditions different types of communication strategies can be used, what forms and methods of teaching argumentation skills are more effective. Even more difficult is the presence of students ' standards for teaching argumentation, i.e., most students do not have a resource platform - diagnostic and epistemological tools. In order to know what abilities need to be improved to teach older adolescents the skills of reasoning in different lessons, we have compiled a description of the levels that will help determine the readiness of the future teacher to learn the skills of argumentation and develop recommendations for their improvement. The characteristics of the levels (high, medium, low) were based on such criteria of readiness of the teacher for training as knowledge, motivational-value, communicative-activity. 
The indicators of these components were: knowledge about the goals, principles and content of argumentation training, effective forms and methods, communicative strategies of argumentation (knowledge component); interest in the study of argumentation pedagogy, focus in argumentation training on the value of preserving and improving the quality of human life, focus on the values of the teaching profession (motivational and value component); possession of oral, written and visual forms of argumentation, formation of meta-skills for teaching argumentation, activity in teaching argumentation in practice at school (communicative-activity).

Here are some examples of questions;

1. What are the main objectives of argumentation training?

2. What are the leading pedagogical principles in teaching argumentation?

3. What should the content in school subjects be in order to teach students arguments?

4. What pedagogical forms can a teacher use to effectively teach older teenagers the skills of argumentation?

5. What methods of teaching argumentation can be called effective?

6. Give examples of effective teaching argumentation in a primary school in different lessons (physics, chemistry, biology, language, and literature).

7. What examples might be interesting for teaching reasoning skills in older adolescence?

8. What are the meanings and values can be called the basis in the training of argumentation?

9. What can be examples of scientific data that clearly illustrate the value of human life?

10. Give examples from your practice of teaching argumentation in school, the results of which influenced not only one student, but the whole group.

11. Identify the steps and procedures you used to effectively teach argumentation in the classroom.

12. How can we increase learning skills and reasoning skills in primary school?

With the help of recording students' answers to questions, it is possible to identify not only the motives in teaching pedagogy of argumentation, which encourage to choose a constructive or destructive learning strategy, but also to qualitatively present all the main components of the readiness of future teachers for this type of activity. It should be noted that the characteristics of the levels of readiness of the future teacher to teach senior teenagers the skills of argumentation will allow university teachers to identify positive and negative trends in the professional development of students. These levels are used by us to build a version of the experimental technique, which implements three approaches - activity, system, and dialogue, which creates conditions for overcoming difficulties in learning.

\section{Results of empirical research}

Data for the experimental work was collected over two years (2018-2019). We conducted an experimental study with 44 students (future teachers of different specialties - teachers of chemistry, biology, Ukrainian language and literature) of the Bogdan Khmelnitsky Melitopol state pedagogical university and State Higher Educational Institution «Krivoy Rog State Pedagogical University» in Ukraine.

With the help of criteria and indicators, we determine the levels of readiness of future teachers to teach older adolescents arguments before the experiment. The data are presented in Table 1. 
Table 1. The levels of readiness of future teachers to teaching older Teens the argument (the initial stage)

\begin{tabular}{|c|c|c|}
\hline \multirow{2}{*}{ The level of readiness } & \multicolumn{2}{|c|}{ Future teachers (44 people) } \\
\cline { 2 - 3 } & Number of people & Indicator, \% \\
\hline High & 6 & $13 \%$ \\
\hline Average & 14 & $32 \%$ \\
\hline Low & 24 & $55 \%$ \\
\hline
\end{tabular}

We divided students into two equivalent groups - control (CG) and experimental (EG) groups (Table 2). Having distributed students according to their groups and having carried out the general analysis of diagnostics, we found out that the measured indicators in both groups are identical.

Table 2. The distribution of the new teachers involved in the teaching experiment, by groups (EG,

CG)

\begin{tabular}{|c|c|c|c|c|}
\hline \multirow{2}{*}{$\begin{array}{c}\text { Readiness } \\
\text { level }\end{array}$} & \multicolumn{2}{|c|}{$\begin{array}{c}\text { Experimental group } \\
\text { (22 students) }\end{array}$} & \multicolumn{2}{c|}{$\begin{array}{c}\text { Control group } \\
\text { (22 students) }\end{array}$} \\
\cline { 2 - 5 } & Number of people & Indicator, \% & Number of people & Indicator, \% \\
\hline High & 3 & $13 \%$ & 3 & $13 \%$ \\
\hline Average & 7 & $32 \%$ & 7 & $32 \%$ \\
\hline Low & 12 & $55 \%$ & 12 & $55 \%$ \\
\hline
\end{tabular}

Therefore, these groups of students from a pedagogical point of view are equivalent at the beginning of the pedagogical experiment, which contributes to the purity of its conduct. We explained the task of the experiment - the development and implementation of experimental methods to increase the level of readiness of future teachers to teach argumentation.

We list experimental methods of teaching future teachers the pedagogy of argumentation.

To work with students, a methodology was developed to increase the level of readiness to teach the arguments of older adolescents in primary school. The following tasks were set:

1) Diagnosis of the state of readiness of future teachers to teach the arguments of older adolescents;

2) Holding of special theoretical and practical seminars;

3) Remedial work and individual consultations for students with different levels of readiness to study argumentation;

4) Analysis of the results of the control diagnosis of the state of readiness of future teachers to teach older adolescents skills and argumentation.

To implement the first task, we conducted various diagnostics with the students of the experimental group, including: the authors' method of assessing the components of readiness of teaching older adolescents the skills of argumentation and conducted interviews that allowed specifying the level of readiness under study.

The questions for conversations were as follows:

1. Do you think you can easily argue your own position during the speeches? 
2. In preparation for the public speaking, can you predict what the alternative views of the audience might be?

3. Is it easy to communicate with your friends to agree on the plan?

4. Do your opponents' opinions interfere with your communication? Provide an example.

5. What are the algorithms which can be used to create a successful argument?

6. What might be the purpose of disputes?

7. Tell us how you usually make plans to achieve good results in teaching argumentation to older teens.

After the interviews, we refined the diagnostic results in the experimental group. The results showed that in the experimental group $13 \%$ of respondents ( 3 students) had a high level, and only 9 $\%$ ( 2 students). Accordingly, the average level of readiness had not $32 \%$ of respondents ( 7 students) but $36 \%$ of students ( 8 people). Data on the distribution of students at a low level of readiness to teach older adolescents skills and argumentation have not changed $-55 \%$ of the respondents (12 students). The results are presented in Table 3.

Table 3. Distribution of students (the experimental group) according to levels of readiness for training reasoning after a thorough diagnosis

\begin{tabular}{|c|c|c|}
\hline \multirow{2}{*}{ Readiness level } & \multicolumn{2}{|c|}{ The experimental group (22 students) } \\
\cline { 2 - 3 } & Number of people & Indicator, \% \\
\hline High & 2 & $9 \%$ \\
\hline Average & 8 & $36 \%$ \\
\hline low & 12 & $55 \%$ \\
\hline
\end{tabular}

The next task of the method was to conduct special theoretical and practical seminars. It was planned to conduct 4 theoretical and 4 practical classes.

Thus, in theoretical classes, we provided information messages, which ended with a question for reflection and preparation of various types of arguments (written, oral, visual). We will provide a list of information messages and related questions.

Message 1. "Argumentation in the professional activity of a secondary school teacher as a complex phenomenon". Question 1. What is more important for a teacher's professional activity - to reveal phenomena, laws, regularities or to teach students to think critically? Why do you think that is?

Message 2. "General principles of teaching skills and argumentation. Recommendations for increasing the level of readiness of future teachers to teach argumentation". Question 2. There are in the list of tasks for each lesson (whether chemistry, biology, physics or language and literature) tasks of argumentation training?

Message 3. "The readiness of the future teacher to teach older teenagers argumentation". Question 3. What do you think should be done to improve your own level of readiness to learn argumentation? What conditions should be created at the university?

Message 4. "Strategy of self-development in teaching pedagogy of argumentation". Question 4. Who can the future teacher get support and assistance in building his own strategy of selfdevelopment in teaching pedagogy of argumentation? 
Message 5. "Values in teaching - the basis of pedagogy argument". Question 5. What values can be used in constructing teaching of pedagogy arguments in working with older adolescents?

To implement the second task of our methodology in the classroom, we provided the following recommendations:

1. Read books, making a list of those where there are the best tips and examples for the construction of arguments.

2. Watch videos where the actors look convincing in their speeches. What dialogic strategies they use (presentation, consensual, manipulative, opposition)?

3. Choose bright visual images that you can use to argue your own statements.

4. Create your own portfolio of pedagogy of argument: pick up diagnostic tasks and create with their analogs new, interesting for older teenagers; pick up accurate theses for each lesson, each presentation, and even for walks and excursions.

5. Think about their own individual psychological characteristics - you can develop them as better?

6. Select the standards of behavior of the teacher in the inheritance. What should be the best teacher?

7. When listening to modern songs, focus not on the melody, but on understanding the content, words, and ideas. What are the values of promoting artists' songs?

Students of the experimental group discussed these recommendations and shared their experiences and experiences.

At the practical seminars, a group of students worked out such mini-classes: "Rational way of thinking", "Ability to argue their own position", "Pedagogical values", "Goals of argumentation", "Skills of reasoned communication", "Ability to influence the opinion of the interlocutor", "Understanding the features of the process of growing older teenager", "Dignity of speech", "does it always make sense in argumentation?", "Creative approach to the organization of teaching pedagogy of argumentation" and the like. These mini-classes were held for 20 minutes and consisted of an introductory, main and final part.

For example, a practical lesson "Does it always make sense to argue?":

1. Introductory part. Presenter: "A teacher who strives for success in teaching argumentation should focus on a positive goal. It is difficult to set real goals in teaching argumentation, but real argumentation can be learned only in a community of people who respect the opinion of another. Such teachers should always set an example of how to do this, and as a result, respect the opinion of all who surround them. Why is difficult to do?".

2. Main part. Read the fable "Wolf and lamb" (you can watch the video). After the fable, questions are asked: What sayings does the lamb use to bring the wolf to its own position? How does the wolf argue its own opinion?

3. Final part. Discussion and reflection: Why is the expression "The strong are always powerless to blame" is the morality of this fable? Does it make sense to argue in the case of aggression that threatens life and security? Give examples from your own experience, in which cases the argument was superfluous?

After the classes, with the help of diagnostics, we clarified the level of future teachers' readiness to teach argumentation in the experimental group. The diagnostics showed that the results were different. The diagnostic results are presented in comparative Table 4, which reflects a certain dynamics in the distribution of readiness levels. 
Table 4. Dynamics in the distribution of students of the experimental group by levels of readiness after theoretical and practical training

\begin{tabular}{|c|c|c|c|c|c|}
\hline \multirow[t]{2}{*}{ Readiness level } & \multicolumn{2}{|c|}{$\begin{array}{c}\text { Data of the experimental group after } \\
\text { in-depth diagnosis } \\
\text { (22 students) }\end{array}$} & \multicolumn{2}{|c|}{$\begin{array}{l}\text { Data the experimental group } \\
\text { after the training } \\
\text { (22 students) }\end{array}$} & \multirow{2}{*}{ 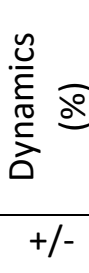 } \\
\hline & people & $\%$ & people & $\%$ & \\
\hline High & 2 & 9 & 4 & 18 & +9 \\
\hline Average & 8 & 36 & 12 & 55 & +19 \\
\hline Low & 12 & 55 & 8 & 27 & -28 \\
\hline
\end{tabular}

The table shows the change in the dynamics of levels of readiness of teachers to selforganization in professional activity. Thus, the high level increased by $18 \%$, the average - by $19 \%$, while the low level decreased by $37 \%$. Such data allow us to talk about the success and effectiveness of the experimental technique, but at the same time, in our opinion, it is necessary to conduct collection and Advisory work, which was aimed at the following task.

Thus, the next task involved corrective work and consultations with students of different levels of readiness and was carried out as follows:

- work with students with a high level of development of readiness for the training of senior pupils of argumentation provided a wide choice of independent actions, promoted development of all components of investigated readiness;

- students with an average level of readiness were involved in the work to change the attitude to the improvement of individual psychological characteristics that affect the processes of success in teaching argumentation pedagogy, the formation of their sustainable motivation to acquire new knowledge, increasing the level of competence;

- students who have a low level of readiness to teach older adolescents the skills and skills of argumentation, in the dialogue it was proposed to find out the reasons for the low motivation, to see what there are gaps in knowledge of the theory of argumentation, ethical foundations of pedagogical activity, practical skills in working with students and the like.

After carrying out this work, we specified the level of readiness of students to teach senior teenagers the skills of argumentation in the experimental group. The results of the control measures are presented in comparative Table 5.

Table 5. Dynamics in the distribution of students of the experimental group by levels of readiness after correctional work

\begin{tabular}{|c|c|c|c|c|c|}
\hline \multirow[t]{2}{*}{$\begin{array}{c}\text { Readiness } \\
\text { level }\end{array}$} & \multicolumn{2}{|c|}{$\begin{array}{c}\text { Data of the experimental group after } \\
\text { in-depth diagnosis } \\
\text { (22 students) }\end{array}$} & \multicolumn{2}{|c|}{$\begin{array}{c}\text { Data the experimental group } \\
\text { after the training } \\
\text { (22 students) }\end{array}$} & \multirow{2}{*}{ 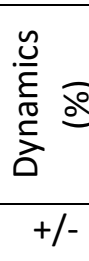 } \\
\hline & people & $\%$ & people & $\%$ & \\
\hline High & 4 & 18 & 5 & 23 & +5 \\
\hline Average & 12 & 55 & 13 & 59 & +4 \\
\hline Low & 8 & 27 & 4 & 18 & -9 \\
\hline
\end{tabular}


The table shows the change in the dynamics of levels of readiness of students to teach older adolescents the ability and skills of argumentation. Such data allow us to talk about the success and effectiveness of correctional work with educators that were part of the experimental group.

At the next stage, we performed general diagnostics in the experimental and control groups. A comparative analysis confirmed that the experimental work has positive results, which is recorded in Table 6.

Table 6. Distribution of students of experimental and control groups by levels of readiness to teach older adolescents the ability and skills of argumentation

\begin{tabular}{|l|c|c|c|c|c|c|c|c|}
\hline \multirow{2}{*}{ Levels } & \multicolumn{4}{|c|}{ Experimental group (EG) } & \multicolumn{4}{c|}{ Control group (CG) } \\
\cline { 2 - 9 } & \multicolumn{2}{|c|}{$\begin{array}{c}\text { Beginning of the } \\
\text { experiment }\end{array}$} & \multicolumn{2}{|c|}{$\begin{array}{c}\text { The end of the } \\
\text { experiment }\end{array}$} & \multicolumn{2}{c|}{$\begin{array}{c}\text { Beginning of the } \\
\text { experiment }\end{array}$} & $\begin{array}{c}\text { The end of the } \\
\text { experiment }\end{array}$ \\
\cline { 2 - 9 } & people & $\%$ & people & $\%$ & people & $\%$ & people & $\%$ \\
\hline High & 3 & 13 & 5 & 23 & 3 & 13 & 3 & 13 \\
\hline Average & 7 & 32 & 13 & 59 & 7 & 32 & 9 & 41 \\
\hline Low & 12 & 55 & 4 & 18 & 12 & 55 & 10 & 46 \\
\hline
\end{tabular}

We checked the data using the Pearson test. The results are presented in Table 7.

Table 7. Experiment calculation table

\begin{tabular}{|l|l|l|l|l|l|}
\hline Levels & $\begin{array}{l}\text { Empirical } \\
\text { frequency } n_{i}\end{array}$ & $\begin{array}{l}\text { Theoretical } \\
\text { frequency } n_{i}^{\prime}\end{array}$ & $n_{i}-n_{i}^{\prime}$ & $\left(n_{i}-n_{i}^{\prime}\right)^{2}$ & \multicolumn{1}{|c|}{$\left(n_{i}-n_{i}^{\prime}\right)^{2} / n_{i}^{\prime}$} \\
\hline High & 23 & 13 & 10 & 100 & 7,6923 \\
\hline Average & 59 & 44 & 18 & 324 & 7,9024 \\
\hline Low & 18 & 46 & -28 & 784 & 17,0435 \\
\hline$\Sigma$ & 100 & 100 & - & - & 32,63822498 \\
\hline
\end{tabular}

\section{Conclusion and discussion}

The construction of a holistic pedagogy of argumentation involves the development and integration of three main areas - the culture of rational thinking, the culture of feeling expression, and mental values in teacher's activities. After all, these values will become the space for the real argumentation in dialogical strategies. The first direction - the culture of rational thinking - is somehow revealed in various materials for studying, the second and the third (the space of their own feelings, mental values) - the prospect for discussion.

Detailed development of pedagogy of argumentation is already planned for different age groups, including the most difficult ones. Here there is an issue of development of moral qualities, development of strategies of reaction to argumentation taking into account polymorphism of thinking, selection of diagnostic and didactic materials.

Understanding the methodological difficulties that arise in future teachers' preparation is inherent in different universities. In this regard, we should pay attention to the concept of educational activities of higher education institutions. B. Gershunsky postulates that the whole "meaning of educational activity is reduced to the influence on the spiritual, moral potential of society, on the mental space in which this society resides" (1998). He suggests that the most 
compelling arguments should be sought in the historical experience of mankind, and for the formation of a new person it is necessary to understand the meaning of his life (Gershunsky, 1998). The basics of professional development of the future teacher are in justice, love, and responsibility. We need the latest developments with detailed comments, with access to various specialties and different cultures within the focus of teaching profession values.

Systematization of interesting exercises, problem dialogues, essays with reflections used at the lessons of Physics, Chemistry, Biology, Literature, etc. can form the basis for the development of integrative lessons in the coming years. Further development of experimental experience in the field of pedagogy of argumentation, which is based on the exchange of methodological experience, will help to create educational materials for the preparation of common world-class curricula.

\section{References}

Acar, Q., Patton, B. R. \& White, A. L. (2015). Prospective Secondary Science Teachers' Argumentation Skills and the Interaction of These Skills with Their Conceptual Knowledge. Australian Journal of Teacher Education, 4O(9). DOI: 10.14221/ajte.2015v40n9.8.

Andrews, R. (1995). Teaching and learning argument. Cassell.

Andrews, R. (2009). Argumentation in Higher Education: Improving Practice Through Theory and Research. Routledge.

Andrews, R. (2013). A Theory of Contemporary Rhetoric. Routledge.

Archila, P. A., Luna-Calderón, P., Mayer, M. (2017). El empleoespontáneo de conectores y vocabulario relacionado con lasciencias: Implicaciones en la argumentaciónes crita, Revista Eureka sobre Enseñanza y Divulgación de las Ciencias, 14(1), 3-23.

Bathgate, M., Crowell, A., Schunn, C., Cannady, M., \& Dorph, R. (2015). The Learning Benefits of Being Willing and Able to Engage in Scientific Argumentation. International Journal of Science Education, 37(10), 1590-1612.

Bërveniku, E. D. (2017). The Art of Argumentation: A Sociolinguistic Approach to Developing Thesis Statements (The Case of Kosova High School Students). Eurasian Journal of Applied Linguistics, 3, 271-286. DOI: 10.32601/ejal.461018.

Bibler, V.S. (1993). Shkola dialoga kultur: Idei. Opyit. Problemyi [School of Dialogue of Cultures: Ideas. Experience. Problems]. Kemerovo: "ALEF", Gumanitarnyiy Tsentr.

Boryitko, N. (2012). Gumanitarnyie printsipy i professionalnogo obrazovaniya pedagoga-vospitatelya $v$ sisteme nepreryivnogo obrazovaniya [Humanitarian principles of vocational education of teachereducator in the system of continuous education]. Izvestiya VGPU: Pedagogicheskie nauki, 11(75), 4145.

Costello, P. J., \& Mitchell, S. (1995). Competing and Consensual Voices: The Theory and Practice of Argument. Multilingual Matters.

Erdogan, I., Ciftci, A., \& Topcu, M. (2017). Examination of the questions used in science lessons and argumentation levels of students. Journal of Baltic Science Education, 16, 980-993.

Fry, H., Ketteridge, S., \& Marshall, S. (2003). A Handbook for Teaching and Learning in Higher Education: Enhancing Academic Practice. Routledge.

Gershunskiy, B. (1998). Filosofiya obrazovaniya [Philosophy of education]. Moskva: Moskovskiy psihologo-sotsialnyiy institut. 
Hekhauzen, H. (2003). Motivatsiya i deyatelnost [Motivation an dactivity]. Sankt-Peterburg: Piter; Moskva: Smyisl.

Ivin, A. (2015). Osnovyi teorii argumentatsii [The basics of the theory of reasoning]. Moskva-Berlin: Direkt-Media.

Killen ${ }_{\llcorner}$R. (2006). Effective Teaching Strategies: Lessons from Research and Practice. Cengage Learning Australia.

Law of Ukraine on Education. Bulletin of the Verkhovna Rada of Ukraine (Asamended by Laws № 2657-VIII dated 18.12.2018; № 2661-VIII dated 12/22/2018), 2017, № 38-39, 380 https://zakon.rada.gov.ua/laws/show/2145-19

Lefevr, V. (2009). Lektsii po teorii refleksivnyih igr [Lectures on the theory of reflexive games], Moskva: Kogito-tsentr.

Llewellyn, D. (2013). Teaching High School Science Through Inquiry and Argumentation. Corwin Press.

Lourenço, A. B., Ferreira, J. Q., \& Queiroz, S. L. (2016). Licenciandos em Química e Argumentação Científica: Tendências nas Ações Discursivas em Sala de Aula. Quim. Nova, 39(4), 513-521. DOI: 10.5935/0100-4042.20160035.

Mitchell, S,. \& Andrews, R. (eds.) (2000). Learning to Argue in Higher Education. Portsmouth: Heinemann.

Namdar, B., \& Tuskan, I. B. (2018). Science Teachers' Views of Scientific Argumentation. Hacettepe University Journal of Education, 33(1), 1-22. DOI: 10.16986/HUJE.2017030137.

Patrick, J. M. Costello (2000). Thinking Skills and Early Childhood Education. David Fulton, 164.

Pro osnovni kompetentsii dlia navchannia protiahom usoho zhyttia: Rekomendatsii 2006/962/ Evropeiskoho Parlamentu ta Rady(leS) vid 18.12.2006. [Recommendation 2006/962 / EC of the European Parliament and of the Council (EC) on core competencies for lifelong learning of December 18, 2006] https://zakon.rada.gov.ua/laws/show/994_975

Roth, W. F., \& Roth, I. M. (2015). Redefining U. S. Education: A systematic approach to teaching. DOI: $10.1201 / \mathrm{b} 18691$.

Shambaugh, N., \& Magliaro, S. (2006) Instructional Design: A Systematic Approach for Reflective Practice. Pearson.

Tihomirov, O. (1984). Psihologiya myishleniya [Psychology of thinking]. Moskva: Moskow University.

Torun, F., \& Şahin, S. (2016). Determination of Students' Argument Levels in Argumentation-Based Social Studies Course. Education and Science, 41(186), 233-251. DOI: 10.15390/EB.2016.6322.

Valitskaya, A., Antonova, O., \& Zhigalko, E. (2006). Urok - sobyitie v kulturotvorcheskoy shkole [Lesson - an event in a culture-raising school]. Urok kak sobyitie kultury i stsenarii: uchebnometodicheskoe posobie. Sankt-Peterburg: Izd-vo RGPU im. A.I. Gertsena, 32.

Villarroel, C., Garcia-Mila, M., Felton, M., \& Miralda-Banda, A. (2019). Efecto de laconsigna argumentativa enlacalidad del diálogo argumentativo y dela argumentaciónes crita, Infancia y Aprendizaje, 42(1), 37-86, DOI: 10.1080/02103702.2018.1550162.

Volkova, N. (2010). Argumentatsiya yak zasib perekonuyuchogo vplivu vchitelya [Argumentation as a means of persuasive influence of the teacher]. Visnik Luganskogo natsionalnogo universitetu Imeni Tarasa Shevchenka, 12(199), 12-25.

Vyigotskiy, L. (1991). Pedagogicheskaya psihologiya [Pedagogical psychology]. Moskva: Pedagogika. 